\title{
Molecular Cytogenetic Characterization of a New T2BL·1RS Wheat-Rye Chromosome Translocation Line Resistant to Stripe Rust and Powdery Mildew
}

\begin{abstract}
Chunmei Wang, Center for Agricultural Resources Research, Institute of Genetics and Developmental Biology (IGDB), Chinese Academy of Sciences (CAS), Shijiazhuang 050021, China; Qi Zheng, The State Key Laboratory of Plant Cell and Chromosome Engineering, IGDB, CAS, Beijing 100101, China; Lihui Li, The National Key Facility for Crop Gene Resources and Genetic Improvement, Institute of Crop Science, Chinese Academy of Agricultural Sciences (CAAS), Beijing 100081, China; Yongchun Niu, Institute of Plant Protection, CAAS, Beijing 100193, China, and Institute of Agricultural Resources and Regional Planning, CAAS, Beijing 100081, China; Haibo Wang, Institute of Genetics and Physiology, Hebei Academy of Agriculture and Forestry Sciences, Shijiazhuang, 050051; Bin Li, The State Key Laboratory of Plant Cell and Chromosome Engineering, IGDB, CAS, Beijing 100101, China; and Xiaotian Zhang, Yunfeng Xu, and Diaoguo An, Center for Agricultural Resources Research, IGDB, CAS, Shijiazhuang 050021, China
\end{abstract}

\begin{abstract}
Wang, C. M., Zheng, Q., Li, L. H., Niu, Y. C., Wang, H. B., Li, B., Zhang, X. T., Xu, Y. F., and An, D. G. 2009. Molecular cytogenetic characterization of a new T2BL·1RS wheat-rye chromosome translocation line resistant to stripe rust and powdery mildew. Plant Dis. 93:124-129.

Wheat (Triticum aestivum) genotypes with rye (Secale cereale) 1RS chromosomal translocations are widely used in wheat breeding programs because 1RS carries genes for resistance to several diseases. However, some of the pathogens have evolved into new races that overcome the resistance due to extensive use of cultivars with the resistance genes from rye. Therefore, identification and deployment of new resistance sources with desirable agronomic characteristics are important and urgent. We have used winter rye cultivar German White as a source of genes for desirable traits in wheat improvement. A new genotype named WR04-32 was produced through hybridization and chromosome manipulation between common winter wheat cultivar Xiaoyan 6 and German White. This genotype was highly resistant to a wide spectrum of the wheat stripe rust (Puccinia striiformis f. sp. tritici) and powdery mildew (Blumeria graminis f. sp. tritici) pathotypes prevalent in China. The polymerase chain reaction (PCR) result using EST-STS (expressed sequence tag-site tagged sequence) marker $S T S_{\mathrm{WE} 126}$ specific to 1RS confirmed 1RS in WR04-32, and it was further proved to be a wheat-rye T2BL-1RS translocation line using sequential genomic in situ hybridization (GISH) and multicolor fluorescence in situ hybridization

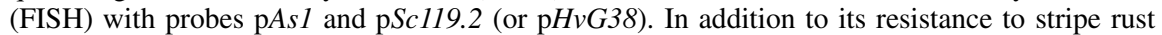
and powdery mildew, WR04-32 was genetically stable and had desirable agronomic traits, making it a desirable germplasm for wheat breeding.
\end{abstract}

Growing resistant cultivars has proved to be an economic, effective, and environmentally friendly means to reduce economic losses caused by epidemics of diseases. However, large-scale growing of a few cultivars with a limited number of race-specific resistance genes has led to rapid changes of virulent races of pathogens, which are seriously threatening wheat (Triticum aestivum) production (26). In recent years, the lack of desirable wheat

Corresponding author: Diaoguo An

E-mail: andiaoguo@163.com

Chunmei Wang and Qi Zheng contributed equally to this work.

Accepted for publication 16 October 2008.

doi:10.1094/PDIS-93-2-0124

() 2009 The American Phytopathological Society germplasm resources has made the genetic variation of common wheat increasingly narrow. Wheat-related wild species in the tribe Triticeae possess many important agronomical characteristics and are desirable to enrich genetic variability of common wheat (4). Rye (Secale cereale L.), a species closely related to wheat, has been extensively used as a valuable source of genes for disease resistance, yield improvement, and environment adaptation (6). Cultivars possessing the T1BL·1RS wheat-rye chromosome translocation carry genes $\operatorname{Yr} 9, \operatorname{Sr} 31, \operatorname{Lr} 26$, and $\operatorname{Pm} 8$ (10) for race-specific resistance to stripe rust (Puccinia striiformis Westend. f. sp. tritici Eriks.), stem rust ( $P$. graminis Pers. f. sp. tritici Eriks. \& Henn.), leaf rust ( $P$. triticina Eriks.), and powdery mildew (Blumeria graminis (DC.) E.O. f. sp. tritici), respectively. These cultivars have been widely grown and extensively used as major sources of disease resistance in many countries since the 1970s (25).

However, race-specific resistances to these diseases have been readily overcome by corresponding virulent races of the pathogens since cultivars with the T1BL-1RS translocation were grown on a large scale $(31,32)$, causing significant losses in wheat production. Cultivars containing the T1BL.1RS translocation are associated with inferior bread-making quality, which restricts their further utilization (12). Genetic vulnerability caused primarily by wide cultivation of T1BL.1RS cultivars results from a narrow genetic base contributed by 1RS from Petkus rye (18). Other rye genotypes have been used to create different wheat-rye translocation germplasm for potential utilization in breeding and production. For example, the T1DL-1RS wheat-rye translocation line derived from Imperial rye carries a stem rust resistance gene $(S r R)$ (21). Qi et al. (17) obtained two wheat-rye hybrids and two amphiploids with powdery mildew resistance genes derived from a Chinese landrace rye Jinzhou Heimai. Ko et al. (7) produced a wheat line possessing the T1BL-1RS translocation derived from a Korean rye cultivar. All of these reports suggest that $S$. cereale has more useful genes to be utilized in wheat breeding to acquire desirable traits. The identification and deployment of new sources of genotypes in S. cereale with desirable traits are, therefore, of importance and urgency.

Winter rye cultivar German White displayed superior resistance to various isolates or races of the stripe rust and powdery mildew pathogens prevalent in China, which makes it a valuable resistant resource for breeding. A new wheat genotype, WR04-32, produced by crossing common winter wheat cultivar Xiaoyan 6 with German White, showed a high level of resistance to both stripe rust and pow- 
dery mildew for several years in various wheat growing areas (unpublished data). The objectives of this study were to determine the genomic composition of WR0432 using molecular cytogenetic methods, characterize its resistance to stripe rust and powdery mildew using the isolates or races of the pathogens prevalent in China, and determine its yield potential.

\section{MATERIALS AND METHODS}

Plant materials. A wheat-rye line, designated WR04-32, was produced by crossing winter wheat ( $T$. aestivum) cultivar Xiaoyan 6 (AABBDD, $2 n=42$ ) with winter rye $(S$. cereale) cultivar German White (RR, $2 n=14$ ). Xiaoyan 6 was developed by Prof. Zhensheng Li and his colleagues from a cross between common wheat and Thinopyrum elongatum in Shaanxi Province, China in 1981 (31). Wheat genotype Mingxian 169 was used as a susceptible check in the tests for resistance to stripe rust and powdery mildew. Shi 4185 , a current representative wheat cultivar for northern China used as a check in national wheat regional trials, possessing the T1BL-1RS translocation, was used as a check in the tests to determine reactions to races of $P$. striiformis $\mathrm{f}$. sp. tritici and isolates of B. graminis f. sp. tritici. Total DNA extracted from wheat genotype Chinese Spring was used as a source of blocking DNA in genomic in situ hybridization (GISH) and fluorescence in situ hybridization (FISH) assays. T1BL·1RS wheat-rye chromosome translocation genotypes Lovrin10 and Lovrin13 (18) and eight other wheat-rye lines derived from Xiaoyan 6 and German White, identified by FISH, were used to detect the presence of chromosome 1RS using an expressed sequence tag-polymerase chain reaction (EST-PCR) marker.

Production of wheat-rye chromosome translocation genotype. Wheat cultivar Xiaoyan 6 was used for crossing with rye cultivar German White in 1996. Sixteen to 18 days after pollination, inflorescences were collected and stored at $4^{\circ} \mathrm{C}$ for 48 to 72 h. Hybrid embryos were isolated from spikes, and 12 plants were obtained by embryo rescue on MS medium (13). Following chromosome doubling with a solution containing $0.05 \%$ colchicine, $1.5 \%$ dimethylsulfoxide, and 5\% MS medium (2), seven amphidiploid plants were obtained and screened for karyotypes by cytological examination. The plants with somatic chromosome numbers $2 n=56$ were tested for resistance to stripe rust and powdery mildew. Four resistant plants were back-crossed as a female parent to Xiaoyan 6, resulting in $38 \mathrm{BC}_{1} \mathrm{~F}_{1}$ seeds. Of $\mathrm{BC}_{1} \mathrm{~F}_{2}$, plants that resembled the wheat parent grew well in the field, and segregation was observed in plant height and reactions to $P$. striiformis $\mathrm{f}$. sp. tritici races and $B$. graminis f. sp. tritici isolates. Three resistant plants with high seed set and wheat-like plant type were then selfpollinated. A wheat-rye line with $2 n=42$ chromosomes was obtained and continually self-pollinated for an additional six generations to produce a genetically stable genotype, designated WR04-32, before molecular cytogenetic characterization, which had desirable agronomic traits such as compact plant type, tight spikes, strong tillering, and high yielding potential.

Assessment of resistance to stripe rust. To assess the reactions of WR04-32 to stripe rust, we initially used a mixture of races CY29, CY30, CY31, CY32, and CYHy-14 of $P$. striiformis f. sp. tritici prevalent in China by artificial inoculation. Seedlings were inoculated with fresh spores using the spraying method (20) in field in early spring at Luancheng AgroEcological Experimental Station, Chinese Academy of Sciences, Shijiazhuang, Hebei. The seedlings of WR04-32 were further tested for their reactions to 28 isolates or races of $P$. striiformis $\mathrm{f}$. sp. tritici by artificial inoculation in a temperature controlled greenhouse at the Institute of Plant Protection, the Chinese Academy of Agricultural Sciences, Beijing. Each of 28 isolates contains different virulence to resistance genes $Y r 1, Y r 2, Y r 3, Y r 4, Y r 6, Y r 7$, Yr8, Yr9, Yr10, Yr17, Yr26, Yr27, YrA, YrAlba, YrCV, YrGaby, YrSD, YrSpP, and/or $\mathrm{YrSu}(14,15)$. Xiaoyan 6, German White, Mingxian 169, and Shi 4185 were also included in the tests. Seedlings were inoculated with fresh spores using the brushing method at the one-leaf stage, incubated in dew chambers at $10^{\circ} \mathrm{C}$ for 24 $\mathrm{h}$, and then transferred to a greenhouse at $18^{\circ} \mathrm{C} / 12^{\circ} \mathrm{C}$ (day/night) with a photoperiod of 12 to $14 \mathrm{~h}$ of light per day $(14,20)$. Infection types (IT) were scored 14 to 15 days after inoculation when pustules were fully developed on the susceptible check, Mingxian 169. The IT of each plant was recorded based on a 0 to 4 scale, of which $0=$ no visible symptoms and signs, $0 ;=$ necrotic flecks without sporulation, $1=$ small uredia with necrosis, $2=$ small to medium sized uredia with necrotic spots, 3 $=$ medium sized uredia with or without chlorosis, and $4=$ large uredia without chlorosis. Plants with an IT score of 0 to 2 were considered resistant, while those with an IT score of 3 to 4 were considered susceptible according to Bariana and McIntosh (3).

Assessment of resistance to powdery mildew. WR04-32 was tested for resistance to powdery mildew using a mixture of $B$. graminis f. sp. tritici isolates prevalent in northern China. These isolates are virulent to wheat genotypes with powdery mildew resistance genes $P m 1, P m 3 a$, Pm3b, Pm3c, Pm3d, Pm3e, Pm3f, Pm5, Pm6, Pm 7, Pm8, Pm17, and/or Pm19, and avirulent to resistance genes $P m 2, P m 4 a$, Pm4b, Pm12, Pm13, Pm16, Pm20, and/or $P m 21$, as determined by testing them on differential genotypes (5). Tests with the mixture of isolates were conducted in a greenhouse using the procedures described by Sheng (23). Briefly, seedlings of WR04-32, Xiaoyan 6, German White, Mingxian 169, and Shi 4185 were inoculated at the one- to two-leaf stage. Infection types were scored 15 days after inoculation when the susceptible check Mingxian 169 was heavily infected, using a scale of 0 to 4 , where $0=$ no visible symptoms, $0 ;=$ necrotic flecks without sporulation, 1 = sparse aerial hypha and little sporulation, diameter of colonies less than $1 \mathrm{~mm}, 2=$ moderate aerial hypha and sporulation, diameter of colonies less than $1 \mathrm{~mm}, 3=$ thick aerial hypha and abundant sporulation, diameter of colonies more than $1 \mathrm{~mm}$, and $4=$ abundant sporulation with more than $80 \%$ of the leaf area covered with aerial hypha. Plants with an IT score of $0,1,2,3$, and 4 were considered immune, highly resistant, resistant, susceptible, and highly susceptible, respectively, according to Sheng (23).

PCR analysis. Genomic DNA was extracted from young green leaves as described by Sharp et al. (22). An EST-STS (expressed sequence tag-site tagged sequence) marker specific to $1 \mathrm{RS}$ chromosome, STS $_{\mathrm{WE} 126}$ (5'-TCAAGCACGCAT TTCAACTC-3' and 5'-ACAGATGTC CAAAGCCCAAC-3') (28), was used to check for the 1RS chromosome translocation in WR04-32. PCR amplification was conducted in a $10-\mu l$ reaction mixture containing $1.0 \mu \mathrm{l}$ of $10 \times$ PCR buffer, $0.8 \mu \mathrm{l}$ of $25 \mathrm{mM} \mathrm{MgCl} 2,0.8 \mu \mathrm{l}$ of $2.5 \mathrm{mM}$ dNTPs, $0.2 \mu \mathrm{l}$ of $10 \mu \mathrm{M}$ primers, $0.1 \mu \mathrm{l}$ of Taq DNA polymerase (5 U/ $\mu$, Promega, Mannheim, Germany), and $20 \mathrm{ng}$ of genomic DNA as template. PCR reaction conditions were $94^{\circ} \mathrm{C}$ for $3 \mathrm{~min}$ followed by 32 cycles of $94^{\circ} \mathrm{C}$ for $0.5 \mathrm{~min}, 53^{\circ} \mathrm{C}$ for $1 \mathrm{~min}$, then $72^{\circ} \mathrm{C}$ for $1 \mathrm{~min}$, and a final extension for $10 \mathrm{~min}$ at $72^{\circ} \mathrm{C}$. The PCR products were separated on $8 \%$ nondenaturing polyacrylamide gels (acrylamide: $N, N$-methylene-bisacylamide $=39: 1)$ and visualized by silver staining (24).

Chromosome preparation. Seeds were germinated on wet filter paper at $23^{\circ} \mathrm{C}$ for $48 \mathrm{~h}$. Root tips of 1 to $2 \mathrm{~cm}$ in length were detached from germinated seeds and pretreated in ice water for $24 \mathrm{~h}$, then fixed in freshly prepared ethanol-acetic acid (3:1, $\mathrm{vol} / \mathrm{vol}$ ) fixation solution for 2 days. The fixed root tips were stained in $1 \%$ acetocarmine for $2 \mathrm{~h}$ and squashed in a drop of $45 \%$ acetic acid. Slides with moderate numbers of cells in somatic metaphase were selected under the microscope. Subsequently, the slides were frozen in liquid nitrogen. After removing the coverslips with a razor blade, the slides were air-dried and stored at $-20^{\circ} \mathrm{C}$ for further use.

GISH analysis. GISH analysis was performed with the slides prepared above to detect rye chromatin in WR04-32 following the procedure described by Zheng et al. (30). The total genomic DNA of German 
White was sheared into 500- to 800-bp fragments by sonication. The sheared DNA was labeled with digoxigenin (digoxigenin-11-dUTP, Roche, Germany) by nick translation and used as the probe. The total genomic DNA of Chinese Spring wheat (ABD genomes) was sheared and used as wheat blocking DNA. The slides were incubated in $100 \mu \mathrm{g} / \mathrm{ml}$ RNase in $2 \times$ SSC (standard saline citrate) at $37^{\circ} \mathrm{C}$ for $1 \mathrm{~h}$ and then denatured in $70 \%$ formamide in $2 \times \mathrm{SSC}$ at $70^{\circ} \mathrm{C}$ for $2 \mathrm{~min}$ followed by dehydration in a chilled graded ethanol series $(70,95$, and $100 \%)$ at $-20^{\circ} \mathrm{C}$. The hybridization solution (approximately $75 \%$ hybridization stringency) containing $50 \%$ ( $\mathrm{vol} / \mathrm{vol}$ ) deionized formamide, $2 \times \mathrm{SSC}$, $10 \%$ (wt/vol) dextran sulfate, $0.1 \mathrm{mg} / \mathrm{ml}$ denatured salmon sperm DNA, $5 \mu \mathrm{g} / \mathrm{ml}$ digoxigenin labeled probes, and 0.5 to 1.25 $\mathrm{mg} / \mathrm{ml}$ sheared wheat genomic DNA as blocker was denatured in boiling water for $10 \mathrm{~min}$. After chilling on ice for $10 \mathrm{~min}, 20$ $\mu \mathrm{l}$ of the denatured hybridization mixture was applied to each slide, covered with a plastic slip, and the hybridization was performed in a humid chamber at $37^{\circ} \mathrm{C}$ overnight. After hybridization, slips were removed and the slides were washed once in $2 \times \mathrm{SSC}$ at $42^{\circ} \mathrm{C}$ for $5 \mathrm{~min}, 30 \%$ formamide$2 \times \mathrm{SSC}$ at $42^{\circ} \mathrm{C}$ for $5 \mathrm{~min}$, and $2 \times \mathrm{SSC}$ at $37^{\circ} \mathrm{C}$ before being transferred to the detection buffer ( $4 \times$ SSC plus $0.2 \%$ Tween 20 ). The slides were then blocked in detection buffer containing 5\% BSA for $25 \mathrm{~min}$. The hybridized probes were detected with antidigoxigenin conjugated by fluorescence isothiocyanate (FITC). The slides were counterstained with propidium iodide (PI, $0.25 \mu \mathrm{g} / \mathrm{ml})$ in the Vectashield mounting medium (Vector Laboratories, Burlingame, CA, USA).

Sequential multicolor FISH analysis. After rinsing the GISH hybridization probes signals, multicolor FISH was carried out according to a similar protocol of GISH with two highly repeated DNA sequences $\mathrm{pAsl}$ (or $\mathrm{pH}$ H38) labeled with digoxigenin-11-dUTP and pSc119.2 labeled with biotin-11-dUTP, respectively. Two probes were mixed at a ratio of $1: 1$ before hybridization. The clone $\mathrm{p} A s \mathrm{l}$ contains a $1-\mathrm{kb}$ repetitive DNA sequence from

Table 1. Infection types on seedlings of wheat and wheat-rye genotypes produced by isolate mixtures of Puccinia striiformis f. sp. tritici (stripe rust) and Blumeria graminis f. sp. tritici (powdery mildew)

\begin{tabular}{lcc}
\hline & \multicolumn{2}{c}{ Infection type $^{\mathbf{a}}$} \\
\cline { 2 - 3 } Cultivar/genotype & $\begin{array}{c}\text { Stripe } \\
\text { rust }\end{array}$ & $\begin{array}{c}\text { Powdery } \\
\text { mildew }\end{array}$ \\
\hline Xiaoyan 6 & 4 & 4 \\
German White (rye) & 0 & 0 \\
Mingxian 169 & 4 & 4 \\
WR04-32 & 1 & 0 \\
Shi 4185 & 4 & 4 \\
\hline
\end{tabular}

a Infection types: 0, immune; 1 , highly resistant; 4 , susceptible.
Aegilops tauschii (19); clone pSc119.2 contains a highly repeated sequence from rye (11); and clone $\mathrm{pHvG38}$ contains the GAA-satellite sequence hybridizing to the class of heterochromatin that is stained by N-banding (16). After hybridization, antidigoxigenin-FITC and avidinrhodamine were used for detection of the two probes simultaneously. The slides were counterstained with 4,6-diamidino-2-phenylindole (DAPI). The cells with good hybridization signals were captured by DVC CCD digital camera. The images captured for each color channel were merged using program Image-Pro Plus 4.0.

\section{RESULTS}

Reaction to stripe rust. When inoculated with the mixture of the currently prevalent races of $P$. striiformis f. sp. tritici, including CY29, CY30, CY31, CY32, and CYHy-14, the genotype WR0432 showed resistant (IT 1), the winter rye German White was immune (IT 0), and the susceptible check, Mingxian 169, and wheat cultivars Xiaoyan 6 and Shi 4185 were highly susceptible (IT 4) (Table 1).

Reactions of WR04-32, in comparison with those of German White and Mingxian 169, to 28 isolates of $P$. striiformis f. sp. tritici are shown in Table 2. WR04-32 was immune (IT 0) to all tested isolates except for resistance (IT 1) to race CY32. Similarly, German White was immune to all the isolates. In contrast,
Mingxian 169 was highly susceptible (IT 4) to these isolates.

Reaction to powdery mildew. When tested with the mixture of isolates of $B$. graminis f. sp. tritici collected from northern China, WR04-32 had IT 0, the same reaction as one of its parents, rye German White that was immune (IT 0). In contrast, the wheat parent, Xiaoyan 6, was susceptible (IT 4). Check genotypes Mingxian 169 and Shi 4185 also showed highly susceptible (IT 4) (Table 1).

PCR analysis of wheat-rye genotype WR04-32. The primers for the EST-STS marker STS $_{\text {WE126 }}$ amplified the expected 850-bp diagnostic fragment in WR04-32 and German White, indicating that WR0432 contains the DNA region specific to chromosome 1RS derived from German White (Fig. 1). The 850-bp fragment also was detected in Lovrin10 and Lovrin13, two T1BL-1RS translocation lines, as well as three other wheat-rye lines derived from Xiaoyan 6 and German White. The fragment was not amplified in Xiaoyan 6, Mingxian 169, and other lines from the Xiaoyan 6 and German White crosses that were proved not to have 1RS by FISH identification.

GISH analysis of wheat-rye genotype WR04-32. A pair of chromosome arms in WR04-32 displayed bright-green hybridization signals, showing that the DNA in these chromosome arms was hybridized by the labeled probes from rye. The break-

Table 2. Infection types on seedlings of wheat and wheat-rye genotypes produced by 28 races or isolates of Puccinia striiformis f. sp. tritici

\begin{tabular}{|c|c|c|c|c|}
\hline \multirow[b]{2}{*}{ Race/isolate } & \multirow[b]{2}{*}{ Virulence to $Y r$ genes $^{b}$} & \multicolumn{3}{|c|}{ Infection type $^{\mathrm{a}}$} \\
\hline & & WR04-32 & $\begin{array}{c}\text { German } \\
\text { White }\end{array}$ & $\begin{array}{c}\text { Mingxian } \\
169\end{array}$ \\
\hline 61009 & 3,A,SD & 0 & 0 & 4 \\
\hline 78028 & $6,7,8, \mathrm{~A}$ & 0 & 0 & 4 \\
\hline 58893 & $27, \mathrm{SD}$ & 0 & 0 & 4 \\
\hline 75078 & $2,3,4,8,10,26,27, \mathrm{~A}, \mathrm{Alba}, \mathrm{CV}, \mathrm{SD}, \mathrm{Su}$ & 0 & 0 & 4 \\
\hline 60105 & 1,27,Alba,CV,SD & 0 & 0 & 4 \\
\hline 59791 & Alba,SD & 0 & 0 & 4 \\
\hline 82517 & 1,2,3,Alba,CV,SD & 0 & 0 & 4 \\
\hline 78080 & $2,3,4,6, \mathrm{~A}, \mathrm{Alba}, \mathrm{CV}, \mathrm{Gaby}, \mathrm{SD}, \mathrm{Su}$ & 0 & 0 & 4 \\
\hline 86094 & $6,7,8,9, \mathrm{~A}$, Gaby & 0 & 0 & 4 \\
\hline 72107 & $1,8,10,27, \mathrm{Su}$ & 0 & 0 & 4 \\
\hline 74187 & $6,27, \mathrm{~A}, \mathrm{Su}$ & 0 & 0 & 4 \\
\hline 86036 & SD & 0 & 0 & 4 \\
\hline 76088 & $6,7,8,27$ & 0 & 0 & 4 \\
\hline 76093 & $1,6,7,8,27$, Gaby & 0 & 0 & 4 \\
\hline 86106 & 1,6,7,Alba,Gaby,SD & 0 & 0 & 4 \\
\hline 68009 & $1,2,6,7,8$, Alba & 0 & 0 & 4 \\
\hline 86107 & 6,7,8,9,A,Alba,Gaby,SD & 0 & 0 & 4 \\
\hline 82061 & $2,3,4,6,9, \mathrm{Alba}, \mathrm{Gaby}, \mathrm{SD}, \mathrm{SpP}, \mathrm{Su}$ & 0 & 0 & 4 \\
\hline 80551 & $1,2,3,6,8,9,27, \mathrm{SD}, \mathrm{Su}$ & 0 & 0 & 4 \\
\hline 85019 & 1,3,4,6,8,Alba,Gaby,SD & 0 & 0 & 4 \\
\hline PE92 & $6,7,8,27, \mathrm{~A}, \mathrm{Gaby}$ & 0 & 0 & 4 \\
\hline CYR26 & $1,3,6,7, \mathrm{~A}$ & 0 & 0 & 4 \\
\hline CYR27 & $1,2,3,6,8,27, \mathrm{~A}, \mathrm{Alba}, \mathrm{SpP}$ & 0 & 0 & 4 \\
\hline CYR29 & 1,2,3,4,6,7,9,17,27,A,Alba,CV,Gaby,SD & 0 & 0 & 4 \\
\hline CYRSu-1 & $1,6,7,8, \mathrm{Su}$ & 0 & 0 & 4 \\
\hline CYR30 & 1,2,3,4,8,9,17,A,Alba,CV,Gaby,SD & 0 & 0 & 4 \\
\hline CYR31 & $1,2,3,4,6,7,9, \mathrm{~A}, \mathrm{Alba}, \mathrm{CV}, \mathrm{Gaby}, \mathrm{Su}, \mathrm{SD}$ & 0 & 0 & 4 \\
\hline CYR32 & $1,2,3,6,7,9,17,27, \mathrm{~A}, \mathrm{Alba}, \mathrm{CV}, \mathrm{SpP}, \mathrm{Su}$ & 1 & 0 & 4 \\
\hline
\end{tabular}

a Infection types: 0, immune; 1, highly resistant; 4, susceptible.

${ }^{\mathrm{b}}$ From Niu et al. $(14,15)$. 
points of the translocation were clear and appeared to be in the centromeric region of wheat chromosomes forming a wheat-rye centromeric fusion chromosome (Fig. 2A and 3A). This confirmed that WR04-32 contains chromosomes translocated from German White rye to wheat. The GISH analysis revealed that most chromosomes at the mitotic metaphase showed only the red signals counterstained with propidium iodide, indicating that they were not hybridized with the probe, and obviously these are chromosomes originating from the wheat parent, Xiaoyan 6.

FISH analysis of wheat-rye genotype WR04-32 after GISH. Following GISH analysis, we used multicolor FISH to determine the chromosome composition of WR04-32. Three probes, pSc119.2 and

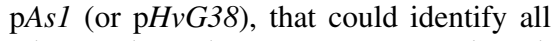
wheat and rye chromosomes were selected. A dispersed pattern was observed on the short arms of the translocation chromosomes of WR04-32 when labeled with $\mathrm{pSc119.2}$. There were two specific pSc119.2 hybridization bands; one was a strong telomeric band and the other was an interstitial band. These results indicated that the short arms were 1RS (Fig. 2B and 3B). The two specific pSc119.2 hybridization bands were also observed on the translocated wheat chromosome arms of WR04-32: one was a strong band at the terminal position and the other was a faint band at the intercalary position (Fig. 2B and $3 \mathrm{~B}$ ). No $\mathrm{p} A s 1$ hybridization signal was detected on the translocation chromosomes (Fig. 2B). When using $\mathrm{pH} v G 38$ probe, we observed two hybridization bands: one was near the centromeric region with a strong signal and the other was at the interstitial position of the translocated wheat chromosomes (Fig. 3B). These results indicated that the long arms of the translocated wheat chromosomes were 2BL (16). Meanwhile, the three probes didn't detect reciprocal translocations among other wheat chromosomes. This confirms that the translocation chromosomes are 2BL·1RS, and WR04-32 had a 2BL·1RS chromosome translocation based on the

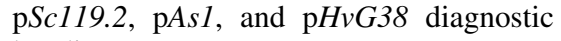
banding pattern.

\section{DISCUSSION}

The wheat-rye T1BL·1RS translocation, possessing resistance genes to powdery mildew and rusts on the 1RS arm, has been widely used in wheat breeding programs and production for many years throughout the world. However, due to the development of virulent races or isolates in the pathogen populations, these resistance genes are no longer effective, including powdery mildew resistance gene $\operatorname{Pm} 8$, stripe rust resistance gene $\mathrm{Yr} 9$, and leaf rust resistance gene $\operatorname{Lr} 26 \quad(31,32)$. T1AL.1RS was another commonly used wheat-rye translocation, and it carried the powdery mildew resistance gene $\mathrm{Pm} 17$ derived from 1RS of Insave rye, but it also has been overcome by new virulent pathotypes (31). This prompted us to search for new sources of resistance genes to deal with new virulent races. In the present study, the genotype WR04-32 we developed, possessing a T2BL.1RS translocation, was highly resistant to races of $P$. striiformis f. sp. tritici and isolates of $B$. graminis f. sp. tritici prevalent in China, some of which were virulent to the $Y r$ and $P m$ genes previously identified from the $1 \mathrm{RS}$ rye chromosome arm. In contrast to Shi 4185 , possessing the T1BL.1RS translocation, which was highly susceptible to many races or isolates of the stripe rust and powdery mildew pathogens, WR04-32 was highly resistant to all tested races or isolates of the pathogens. The results suggest that WR04-32 may have new genes for resistance to stripe rust and powdery mildew. These genes should be derived from the German White rye genotype. It is also possible that the interactions of the rye genes with genes in Xiaoyan 6 wheat provide resistance against the wide range of races or isolates of the stripe rust and powdery mildew pathogens. However, more genetic and molecular mapping studies are needed to identify the resistance genes and determine gene interactions.

The translocation genotypes involving 1RS are still widely used because they have characteristics of high yield and wide adaptation (25). The nature of the yield advantage is associated with the translocations of $1 R S$ in wheat. It may be due to a heterotic effect of the presence of rye chromosome (9). We found that the number of spikes per plant, the number of kernels per spike, the 1,000-kernel weight, and the grain yield per plant of WR04-32 were all higher than those of Shi 4185 . The mean grain yield/ha of WR04-32 was 9.29\% higher than that of Shi 4185 (unpublished data), indicating that WR04-32 possessed favorable agronomic traits required for wheat breeding. Not surprisingly, a perceived yield advantage of WR04-32 could result from the T2BL·1RS translocation.

Xiaoyan 6 is still widely grown in various wheat-producing regions in China because it has good quality and high yield, earliness, stress tolerance, and wide adaptation. However, it was not resistant to powdery mildew and stripe rust in the seedling stage $(1,31)$. Xiaoyan 6 has high-temperature resistance to stripe rust and has some effects on reduction of stripe rust epidemics on adult-plant stage in the field (29). However, seedling resistance is very important to control stripe rust in key epidemic areas, such as Longnan and Longdong areas of Gansu province in China. The introgression of chromosome 1RS into the Xiaoyan 6 genetic background would lead to improvement of disease resistance as well as yield potential. The new genotype W04-32 derived from Xiaoyan 6 and German White showed high resistance to stripe rust and powdery mildew in both seedling and adult-plant stages, and better agronomic traits. Therefore, W04-32 should be a new valuable germplasm for wheat breeding programs, and also could be directly used in wheat production.

Expression sequence tag markers are especially valuable as molecular markers because they are derived from gene transcripts and are more likely to be conserved among gene transcripts in related species, especially on rye, barley, and wheat (8). Recent increase in the availability of EST for wheat deposited in a public database has facilitated the development of EST-STS, which could be directly designed based on EST sequences. Wang et al. (27) screened chromosome-specific STS markers for chromosome $1 \mathrm{~V}$ of Haynaldia vollosa and $1 \mathrm{RK}^{\# 1}$ of Roegneria kamoji using wheat ESTs. In the present study, we used the primers for the EST-STS marker, STS $\mathrm{WE} 126$ (28), which further proved that WR04-32 possesses chromosome 1RS of rye.

Sequential GISH and multicolor FISH techniques showed their advantage in analysis and identification of alien chromosome or chromosome segments introgressed into the wheat genome. Using two repeated sequences, $\mathrm{pSc} 119.2$ (or $\mathrm{pHvG38}$ ) and $\mathrm{p} A s 1$, as probes, Zheng et al. (30) identified eight wheat-Thinopyrum ponticum translocations bearing blue-grained gene(s). In the present study, WR04-32 was proved to be a new wheat-rye T2BL·1RS translocation by using sequential GISH and FISH with two probes,

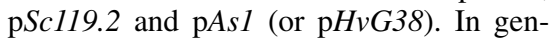

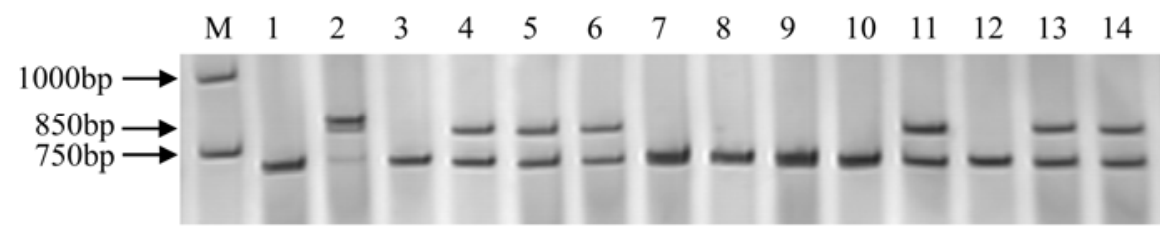

Fig. 1. Polymerase chain reaction (PCR) amplification of the STS WE126 $_{\text {EST-STS (expressed sequence }}$ tag-site tagged sequence) marker specific to $1 \mathrm{RS}$ of rye in wheat-rye lines derived from Xiaoyan 6 wheat and German White rye, and wheat checks. M: Marker DL2000; 1: Xiaoyan 6; 2: German White; 3: Mingxian 169; 4: Lovrin10; 5: Lovrin13; 6: WR04-32; 7, 8, 9, 10, and 12: lines from the Xiaoyan 6/German White cross without 1RS by fluorescence in situ hybridization (FISH); and 11, 13, and 14: lines from the Xiaoyan 6/German White cross with 1RS by FISH. The 850-bp band indicates the diagnostic DNA fragments specific to chromosome 1RS. 
eral, the results from GISH, FISH, and PCR identification were consistent with each other and proved that the chromosome composition of WR04-32 was $2 n=$ $40 \mathrm{~W}+\mathrm{DT}(2 \mathrm{BL} \cdot 1 \mathrm{RS})$.

\section{ACKNOWLEDGMENTS}

Financial support was provided by the Ministry of Science and Technology of China (\#2006CB101700， 2006BAD13B02, and 2006AA10Z1D4) and the Knowledge Innovation Program of Chinese Academy of Sciences
(\#KSCX-YW-09). The authors are gratefully to Luancheng Agro-Ecosystem Experimental Station, Chinese Academy of Sciences for providing the trial site. The authors would also like to thank the reviewers for their valuable comments on the manuscript.
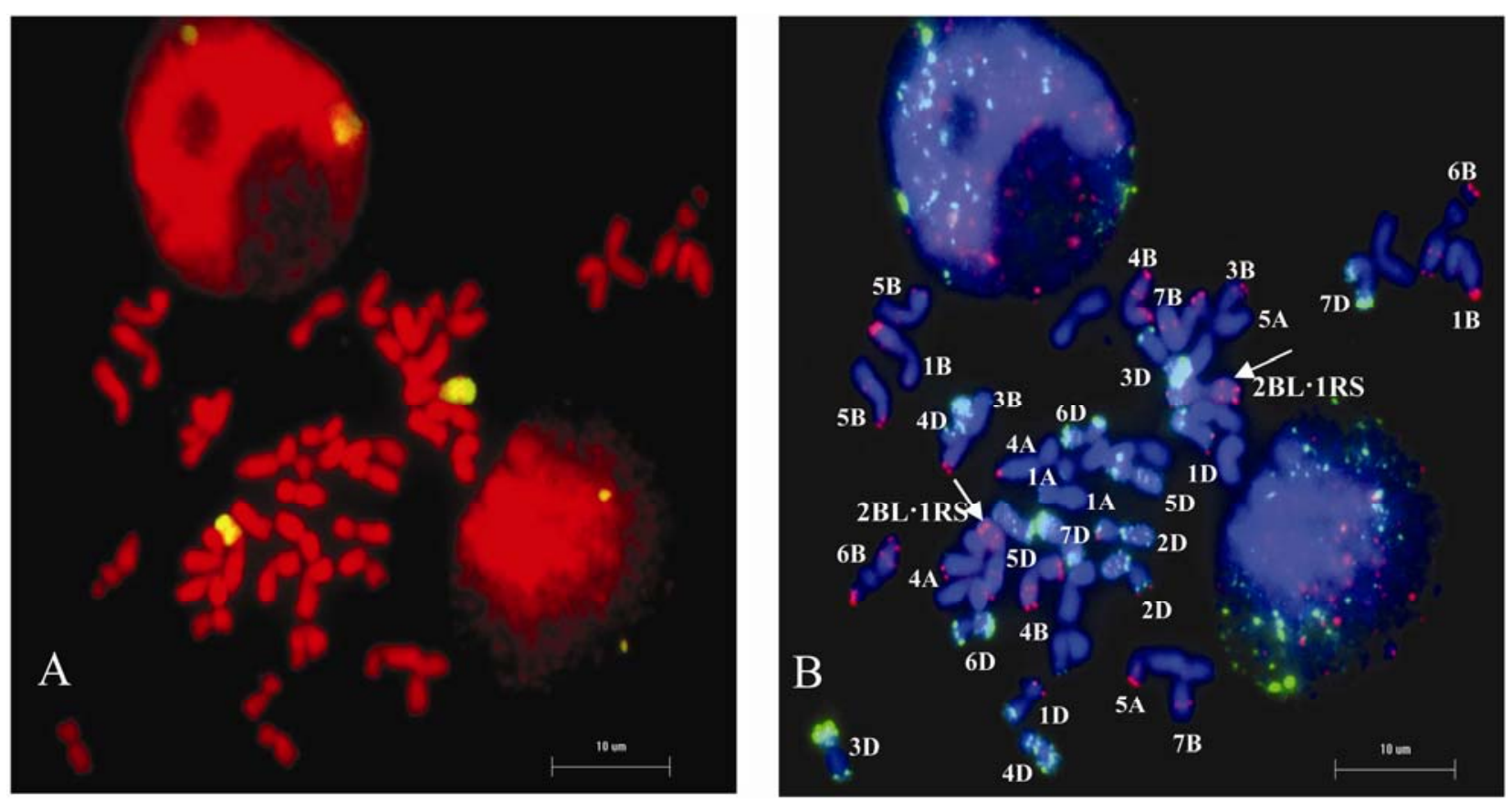

Fig. 2. A (left): Genomic in situ hybridization (GISH) analysis of the wheat-rye translocated chromosomes in WR04-32. Bright yellow signals mark rye chromosomal segments. Wheat chromosomes were counterstained with PI (red). B (right): Sequential multicolor fluorescence in situ hybridization (FISH) on the same metaphase after GISH analysis of translocation line WR04-32 by pAs1 (green) and $\mathrm{pSc} 119.2$ (red) simultaneously. Arrows show the translocated chromosomes $2 \mathrm{BL} \cdot 1 \mathrm{RS}$.
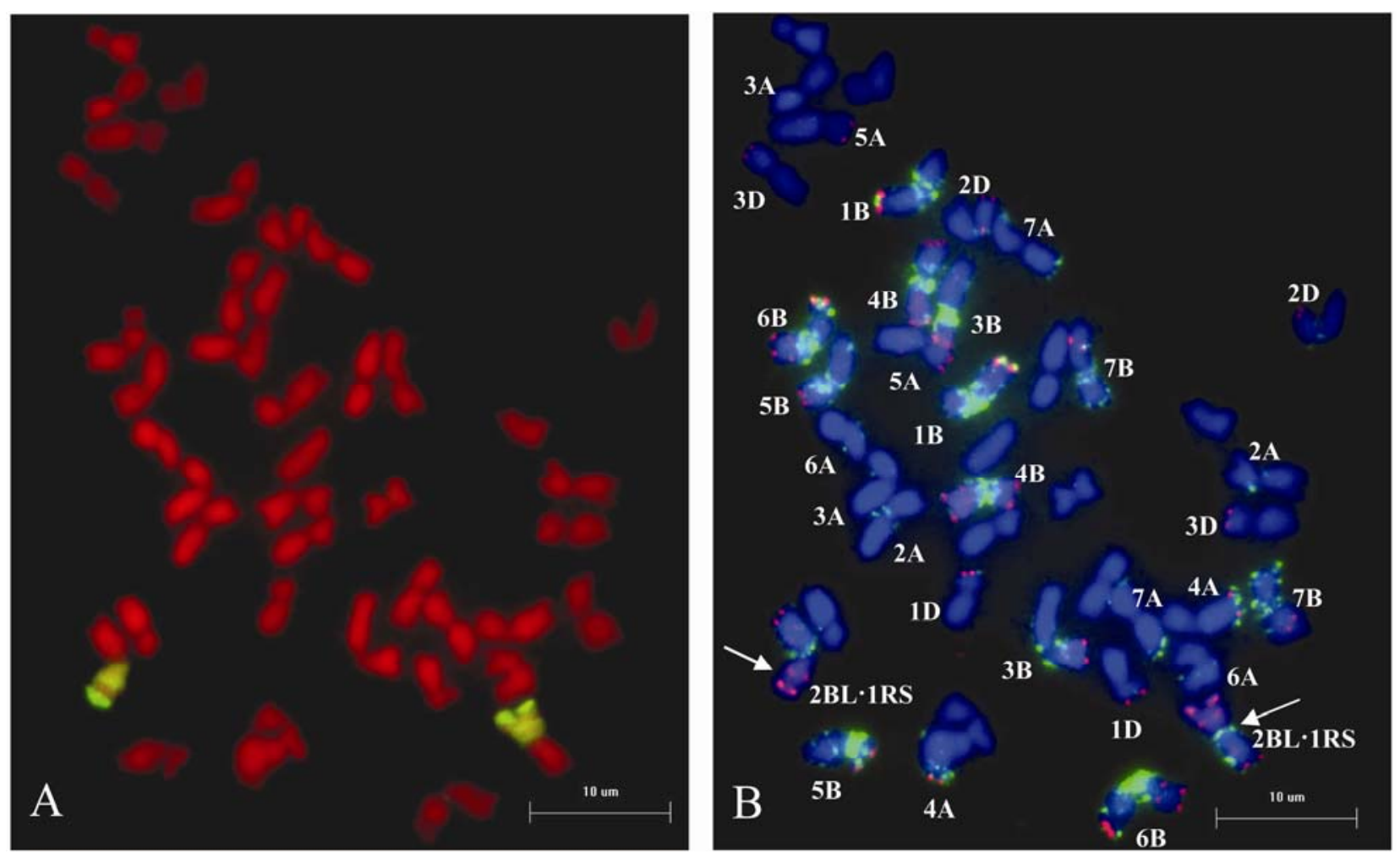

Fig. 3. A (left): Genomic in situ hybridization (GISH) analysis of the wheat-rye translocated chromosomes in WR04-32. Bright yellow signals mark rye chromosomal segments. Wheat chromosomes were counterstained with PI (red). B (right): Sequential multicolor fluorescence in situ hybridization (FISH) on the same metaphase after GISH analysis of translocation line WR04-32 by pHvG38 (green) and pSc119.2 (red) simultaneously. Arrows show the translocated chromosomes $2 \mathrm{BL} \cdot 1 \mathrm{RS}$. 


\section{LITERATURE CITED}

1. An, D. G., Li, L. H., Li, J. M., Li, H. J., and Zhu, Y. G. 2006. Introgression of resistance to powdery mildew conferred by chromosome $2 \mathrm{R}$ by crossing wheat nullisomic $2 \mathrm{D}$ with rye. J. Integrative Plant Biol. 48:838-847.

2. An, D. G., Zhong, G. C., Li, J. M., Wang, Z. G., Wang, Y. M., and Ji, J. 2003. Chromosome doubling methods of immature embryo plants of wheat distant hybridization. Acta Agro. Sin. 29:955-957.

3. Bariana, H. S., and McIntosh, R. A. 1993. Cytogenetic studies in wheat. XV. Location of rust resistance genes in VPM1 and their genetic linkage with other disease resistance genes in chromosome 2A. Genome 36:476-482.

4. Dong, Y. S., Zhou, R. H., Xu, S. J., Cauderon, Y., and Wang, R. C. 1992. Desirable characteristics in perennial Triticease collected in China for wheat improvement. Hereditas 116:176-178.

5. Duan, X. Y., Sheng, B. Q., Zhou, Y. L., and Xiang, Q. J. 1998. Monitoring of the virulence population of Erysiphe graminis DC. f. sp. tritici E. Marchal. Acta Phytophyl. Sin. 25:31-36.

6. Friebe, B., Jinang, J., Raupp, W. J., MaIntosh, R. A., and Gill, B. B. 1996. Characterization of wheat-alien translocations conferring resistance to diseases and pest: Current status. Euphytica 91:385-389.

7. Ko, J. M., Seo, B. B., Suh, D. Y., Do, G. S., Park, D. S., and Kwack, Y. H. 2002. Production of a new wheat line possessing the 1BL.1RS wheat-rye translocation derived from Korean rye cultivar Paldanghomil. Theor. Appl. Genet. 104:171-176.

8. LaRota, M., and Sorrells, M. E. 2004. Comparative DNA sequence analysis of mapped wheat ESTs reveals the complexity of genome relationships between wheat and rice. Funct. Integr. Genomics 4:34-46.

9. Lukaszewski, A. J. 2000. Cell biology \& molecular genetics: Manipulation of the $1 \mathrm{RS} \cdot 1 \mathrm{BL}$ translocation in wheat by induced homoeologous recombination. Crop Sci. 40:216-225.

10. McIntosh, R. A., Hart, G. E., Devos, K. M., Gale, M. D., and Rogers, W. J. 1998. Catalogue of gene symbols for wheat. Pages 123172 in: Proc. Int. Wheat Genet. Sympos., 9th.
A. E. Slinkard, ed. University of Saskatchewan, Saskatoon, Sasktchewan, Canada. Vol. 5.

11. McIntyre, C. L., Pereira, S., Moran, L. B., and Appels, R. 1990. New Secale cereale (rye) DNA derivatives for the detection of rye chromosome segments in wheat. Genome 33:635-640.

12. McKendry, A. L., Tague, D. N., Finney, P. L., and Miskin, K. E. 1996. Effect of 1BL/1RS on milling and baking quality of soft red winter wheat. Crop Sci. 36:848-851.

13. Murashige, T., and Skoog, F. 1962. A revised medium for rapid growth and bioassays with tobacco tissue culture. Physiol. Plant. 15:473497.

14. Niu, Y. C., Qiao, Q., and Wu, L. R. 2000. Postulation of resistance genes to stripe rust in commercial wheat cultivars from Henan, Shandong and Anhui provinces. Acta Phytophyl. Sin. 30:122-128.

15. Niu, Y. C., Wu, L. R., Qiao, Q., and Wan, A. M. 2000. Virulence analysis of main races and pathotypes of wheat yellow rust from China. Proc. Asian Conf. Plant Pathol., 1st. Beijing, 251.

16. Pedersen, C., and Langridge, P. 1997. Identification of the entire chromosome complement of bread wheat by two-color FISH. Genome 40:589-593.

17. Qi, Z. J., Zhuang, L. F., Liu, D. J., and Chen, P. D. 2000. Transfer of germplasm from $\mathrm{Se}$ cale cereale cv. Jingzhou Heimai into cultivated wheat. J. Nanjing Agric. Univ. 23:1-4.

18. Rabinovich, S. V. 1998. Importance of wheatrye translocations for breeding modern cultivars of Triticum aestivum L. Euphytica 100:323-340.

19. Rayburn, A. L., and Gill, B. S. 1986. Molecular identification of the D genome chromosomes of wheat. J. Hered. 77:253-255.

20. Roelfs, A. P., Singh, R. P., and Saari, E. E. 1992. Rust diseases of wheat: Concepts and methods of disease management. CIMMYT, Mexico.

21. Rogowsky, P. M., Guidel, F. L. Y., and Langridge, P. 1991. Isolation and characterization of wheat-rye recombinants involving chromosome arm 1DS of wheat. Theor. Appl. Genet. 82:537-544.
22. Sharp, P. J., Kreis, M., and Shewry, P. 1988 Location of $\beta$-amylase sequence in wheat and its relatives. Theor. Appl. Genet. 75:289-290.

23. Sheng, B. Q. 1988. Powdery mildew scored by infection reaction pattern at the seedling stage. Plant Prot. 14:49-50.

24. Tixier, M. H., and Sourdille, P. M. S. 1997. Detection of wheat microsallite using noradioactive silver nitrate staining method Genet. Breed. 51:175-177.

25. Villareal, R. L., Banuelos, O., Mujeeb-Kazi, A., and Rajaram, S. 1998. Agronomic performance of chromosome $1 \mathrm{~B}$ and T1BL.1RS near-isolines in the spring bread wheat Seri M82. Euphytica 103:195-202.

26. Wan, A., Zhao, Z., Chen, X., He, Z., Jin, S. Jia, Q., Yao, G., Yang, J., Wang, B., Li, G., Bi, Y., and Yuan, Z. 2004. Wheat stripe rust epidemic and virulence of Puccinia strifformis $\mathrm{f}$ sp. tritici in China in 2002. Plant Dis. 88:896904.

27. Wang, C. M., Feng, Y. G., Zhuang, L. F., Cao, A. Z., and Chen, P. D. 2007. Screening of chromosome-specific markers for chromosome $1 \mathrm{R}$ of Secale cereale, 1V of Haynaldia villosa and $1 \mathrm{Rk}^{\# 1}$ of Roegneria kamoji. Acta Agro. Sin. 33:1741-1747.

28. Wang, C. M., Li, L. H., Zhang, X. T., Gao, Q., Wang, R. F., and An, D. G. 2009. Development and application of EST-STS markers specific to chromosome 1RS of Secale cereale. Cereal Res. Commun. In press.

29. Yao, Q. Y., Xu, Z. B., Wang, M. N., Jing, J. X., and Shang, H. S. 2006. Inheritance analysis of stripe rust resistance of wheat cultivar Xiaoyan 6 under the high temperature. Acta Phytophyl. Sin. 33:118-121.

30. Zheng, Q., Li, B., Zhang, X. Y., Mu, S. M., Zhou, H. P., and Li, Z. S. 2006. Molecular cytogenetic characterization of wheat Thinopyrum ponticum translocations bearing blue-grained gene(s) induced by $r$-ray. Euphytica 152:51-60.

31. Zhuang, Q. S. 2003. Chinese Wheat Improvement and Pedigree Analysis. Chinese Agricultural Press, Beijing.

32. Zhuang, Q. S., and Li, Z. S. 1993. Present status of wheat breeding and related genetic study in China. Wheat Inf. Serv. 76:1-15. 